Bernard Długosz ${ }^{1}$

http://dx.doi.org/10.18778/8088-306.2.02

\title{
Czy spółka cywilna może być uznana za pracodawcę w myśl art. 3 k.p.?
}

Pojęcie pracodawcy zostało wprowadzone do polskiego porządku prawnego przez art. 1 pkt 3 ustawy z dnia 2 lutego $1996 \mathrm{r}$. o zmianie ustawy Kodeks pracy oraz o zmianie niektórych ustaw ${ }^{2}$ i do tej pory było przedmiotem licznych wypowiedzi judykatury ${ }^{3}$. Definicję legalną tego pojęcia zawiera art. 3 ustawy z dnia 26 czerwca 1974 r. Kodeks pracy4, zgodnie z którym pracodawcą jest jednostka organizacyjna, choćby nie posiadała osobowości prawnej, a także osoba fizyczna, jeżeli zatrudniają one pracowników.

Z uwagi na to, iż pracodawcą jest jednostka organizacyjna nieposiadająca osobowości prawnej, wiele wątpliwości budzi zagadnienie, kto jest pracodawcą w przypadku spółki cywilnej. Czy jest nim niemająca osobowości prawnej spółka cywilna, czy są nim wszyscy wspólnicy spółki cywilnej, czy może jest nim każdy bądź tylko niektórzy ze wspólników. Odpowiedź na to pytanie rodzi szereg konsekwencji praktycznych dla podmiotów działających w tej formie organizacyjnej.

Z punktu widzenia przepisów ustawy z 23 kwietnia 1964 r. Kodeks cywilny5, jest ona jedynie jedną z nazwanych umów cywilnoprawnych. Nie jest odpowiednikiem spółki osobowej ani kapitałowej, w rozumieniu prawa handlowego, nie posiada osobowości prawnej, a więc nie stanowi także podmiotu prawa. Dlatego posługiwanie się pojęciem,

\footnotetext{
${ }^{1}$ Doktorant, Uniwersytet Łódzki, Wydział Prawa i Administracji, Katedra Postępowania Cywilnego II.

2 Ustawa z dnia 2 lutego 1996 r. o zmianie ustawy Kodeks pracy oraz o zmianie niektórych ustaw, Dz.U. z 1996 r. Nr 24, poz. 110 ze zm.

3 Wyrok SN z dnia 19 września 1996 r., I PRN 101/95, OSNP 1997, nr 7, poz. 112; wyrok SN z dnia 19 grudnia 1997 r., I PKN 448/97, OSNP 1998, nr 22, poz. 649; wyrok SN z dnia 18 lutego 1998 r., II UKN 525/97, OSP 1999, nr 7-8, poz. 130; wyrok SN z dnia 20 października 1998 r., I PKN 390/98, Wspólnota 2000, nr 6, poz. 19; wyrok SN z dnia 22 sierpnia 2003 r., I PK 284/02, OSNP 2004, nr 17, poz. 297; wyrok SN z dnia 4 listopada 2004 r., I PK 25/04, OSNP 2005, nr 14, poz. 206; wyrok SN z dnia 18 października 2011 r., III UK 22/11, OSNP 2012, nr 21-22, poz. 266; wyrok SN z dnia 18 września 2013 r., II PK 4/13, Legalis nr 736942; uchwała SN z dnia 3 sierpnia 2007 r., I PZP 7/07, OSNP 2008, nr 5-6, poz. 55.

${ }^{4}$ Ustawa z dnia 26 czerwca 1974 Kodeks pracy, tekst jedn. Dz.U. z 2014 r., poz. 1502 ze zm., dalej jako: k.p., kodeks pracy.

5 Ustawa z dnia 23 kwietnia 1964 r. Kodeks cywilny, tekst jedn. Dz.U. z 2014 r., poz. 121 ze zm., dalej jako: k.c., kodeks cywilny.
} 
iż określoną czynność dokonała spółka cywilna, jest w istocie skrótem myślowym. Spółka cywilna nie może w ogóle działać, tak samo jak działać nie może umowa zlecenia, czy umowa o dzieło. Na gruncie cywilistycznym, mówiąc „spółka cywilna” mamy na myśli jedynie umowę.

W ujęciu historycznym w judykaturze wyrażano stanowisko, iż wyodrębniona jednostka organizacyjna spółki cywilnej zatrudniająca pracowników jest zakładem pracy w rozumieniu art. 3 k.p. i ma zdolność sądową i procesową ${ }^{6}$. Prezentowane stanowisko miało swoje źródło w treści art. 2 ust. 2 ustawy z dnia 23 grudnia 1988 r. o działalności gospodarczej 7 . Przepis ten wprowadził do systemu prawa pojęcie „przedsiębiorcy”, za którego ustawa uważała także jednostkę organizacyjną nie mającą osobowości prawnej, a utworzoną zgodnie z przepisami prawa, jeżeli jej przedmiot działania obejmował prowadzenie działalności gospodarczej. W tej sytuacji spółka cywilna w zakresie prowadzonej działalności gospodarczej była traktowana jako przedsiębiorca, a co za tym idzie nie mogła być utożsamiana z tworzącymi ją wspólnikami ${ }^{8}$. Kwalifikowanie spółki cywilnej w świetle tej ustawy jako jednostki organizacyjnej było zatem nieodzowne, skoro spółkę tę uznano za podmiot gospodarczy (przedsiębiorcę), chociaż nie była ona osobą fizyczną ani osobą prawną9. Takie ujmowanie spółki cywilnej na gruncie ww. ustawy doprowadziło do posługiwania się w celu oddania charakteru prawnego spółki cywilnej pojęciami podmiotowości prawnej lub podmiotowości gospodarczej ${ }^{10}$.

Zdolność pracodawcza spółki cywilnej jest również szeroko przyjmowana w piśmiennictwie ${ }^{11}$. Zdaniem niektórych autorów treść

\footnotetext{
6 Uchwała SN (7) z dnia 14 stycznia 1993 r., II UZP 21/92, PiZS 1993, nr 12, s. 82; wyrok SN z dnia 7 listopada 1995 r., I PRN 84/95, OSNP 1996, nr 12, poz. 170; wyrok SN z dnia 10 maja 1996 r., I PRN 63/95, OSNAPiUS 1996, nr 23, poz. 335; wyrok SN z dnia 6 lutego 1997 r., I PKN 77/96, OSNP 1997, nr 18, poz. 340; wyrok SN z dnia 8 maja 1998 r., III RN 34/98, OSNP 1999, nr 5, poz. 157; postanowienie SN z dnia 29 stycznia 1999 r., II UKN 507/98, OSNP 2000, nr 11, poz. 447; wyrok NSA z dnia 3 lutego 2011 r., II FSK 838/2010, LexPolonica nr 256097.

7 Ustawa z dnia 23 grudnia 1988 r. o działalności gospodarczej, Dz.U. Nr 41, poz. 324 ze zm.

${ }^{8}$ Wyrok SN z dnia 4 marca 2015 r., I UK 255/14, Legalis nr 1242096.

9 Wyrok NSA z dnia 9 kwietnia 1991 r., SA/Wr 48/01, ONSA 1991, nr 3-4, poz. 56, wyrok NSA z dnia 12 lutego 1996 r., II SA 191/94, Prawo Gospodarcze 1996, nr 5, s. 13 i nast.

10 Uchwała SN z dnia 27 maja 1993 r., III CZP 61/93, OSNC 1994, nr 1, poz. 7.

$11 \mathrm{~T}$. Liszcz, Skutki prawne śmierci pracownika i śmierci pracodawcy w zakresie stosunku pracy, „Praca i Zabezpieczenie Społeczne” 1997, nr 7-8, s. 36; K. Flaga-Gieruszyńska, [w:] Komentarz do Kodeksu postępowania cywilnego, red. A. Zieliński, Warszawa 2010, s. 633; W. Musialski, Kodeks pracy. Komentarz, Warszawa 2009, s. 212; M. Barzycka-Banaszczyk, Kodeks pracy. Komentarz, Warszawa 2008, s.115.
} 
art. 3 k.p. przesądza o podmiotowości prawnej spółki cywilnej w zakresie stosunków pracy. Spółka cywilna jest jednostką organizacyjną, ponieważ polega na współdziałaniu wspólników w celu osiągnięcia wspólnego celu gospodarczego, posiada określony sposób kierowania i reprezentacji jej spraw oraz posiada samodzielny, wyodrębniony majątek-upoważnienie prawne do dokonywania czynności majątkowych we własnym imieniu w zakresie stosunków pracy ${ }^{12}$. Spółka cywilna może być następcą prawnym w stosunkach pracy łączących jej wspólnika jako przedsiębiorcę z pracownikami zatrudnionymi przy prowadzeniu przez niego samodzielnej działalności gospodarczej13.

Niektóre judykaty wskazywały, iż pracodawcą nie może być umowa spółki cywilnej. Nie może być też nim samo przedsiębiorstwo rozumiane jako zespół składników majątkowych, gdyż sam zespół składników majątkowych, w tym m.in. rzeczy ruchome czy nieruchome, nie ma podmiotowości. Pracodawcą jest przedsiębiorca, który jako osoba fizyczna prowadzi działalność na podstawie wpisu do ewidencji działalności gospodarczej, nie zaś prowadzone przez niego przedsiębiorstwo jako zorganizowany zespół składników materialnych i niematerialnych przeznaczonych do prowadzenia działalności gospodarczej ${ }^{14}$.

Kluczową rolę w zmianie podejścia do omawianego zagadnienia spowodowały działania legislacyjne, ponieważ ustawa o działalności gospodarczej została uchylona z dniem 1 stycznia 2001 r. przez art. 99 pkt 2 ustawy z dnia 19 listopada 1999 r. Prawo działalności gospodarczej ${ }^{15}$, którą następnie uchylono przez obowiązującą obecnie ustawę z dnia 2 lipca 2004 r. o swobodzie działalności gospodarczej16. W świetle treści art. 2 ust. 2 ustawy Prawo działalności gospodarczej oraz art. 4 ust. 1 ustawy o swobodzie działalności gospodarczej, za przedsiębiorcę nie uznaje się już jednostki organizacyjnej niemającej osobowości prawnej. Przedsiębiorcą w rozumieniu tych przepisów jest osoba fizyczna, osoba prawna oraz niemająca osobowości prawnej

\footnotetext{
12 J. Skoczyński, Glosa do uchwały składu siedmiu sędziów SN z 14.01.1993 r., II UZP 21/92, „Praca i Zabezpieczenie Społeczne” 1993, nr 12, s. 83; J. Romańczuk, Glosa do uchwały składu siedmiu sędziów SN z 14.01.1993 r., II UZP 21/92, „Praca i Zabezpieczenie Społeczne" 1993, nr 9, s. 74.

13 Wyrok SN z dnia 5 września 2001 r., I PKN 830/00, OSNP 2003, nr 15, poz. 355.

14 Wyrok SN z dnia 22 sierpnia 2003 r., I PK 284/02, OSNP 2004, nr 17, poz. 297.

15 Ustawa z dnia 19 listopada 1999 r. Prawo działalności gospodarczej, Dz.U. Nr 101, poz. $1178 \mathrm{ze} \mathrm{zm}$.

16 Ustawa z dnia 2 lipca 2004 r. o swobodzie działalności gospodarczej, tekst jedn. Dz.U. z 2015 r., poz. 584 ze zm., dalej jako: SwobDziałGospU, Ustawa o swobodzie działalności gospodarczej.
} 
spółka prawa handlowego, która zawodowo, we własnym imieniu podejmuje i wykonuje działalność gospodarczą. Za przedsiębiorców uznaje się także wspólników spółki cywilnej w zakresie wykonywanej przez nich działalności gospodarczej.

Zadziwiające jest w tej materii stanowisko Naczelnego Sądu Administracyjnego - wyrażone w stosunkowo młodym orzeczeniu - który pomimo tego, iż dostrzegł zmianę przepisów, jaka weszła w życie 1 stycznia 2001 r., zgodnie z którą już nie spółka cywilna, a wspólnicy mają status przedsiębiorców, to zdaniem NSA nie spowodowało to zmiany w prawie pracy, gdzie na gruncie ustawy Kodeks pracy pracodawcą nadal może być spółka cywilna, a zatem do niej kierowane muszą być decyzje dotyczące publicznoprawnych obowiązków pracodawcy ${ }^{17}$.

Pochodzenie spółki cywilnej w polskim prawodawstwie bierze swój początek z Kodeksu Napoleona, o spółce traktowały art. 18321873. Już wtedy miała ona specyficzną formę, bowiem była kontraktem, przez który dwie lub więcej osób godzi się do dania jakiejś rzeczy na „współkę”, w celu podzielenia się zyskiem, jaki może wyniknąć. Spółka cywilna w Polsce jest jedyną w swoim rodzaju instytucją prawną na skalę całej Europy. Na przykład w Niemczech jest to jedna ze spółek osobowych.

Odnosząc się do charakteru prawnego spółki cywilnej, należy podkreślić, iż spółka cywilna jest stosunkiem o charakterze zobowiązaniowym (umową) zawartym pomiędzy co najmniej dwoma podmiotami. Tym samym nie tylko nie posiada osobowości prawnej, ale również zdolności sądowej i procesowej, upadłościowej, układowej ani wekslowej18. Spółka cywilna nie jest także przedsiębiorcą w rozumieniu art. 431 k.c. ani art. 4 ust. 1 SwobDziałGospU. Spółka nie może być również podmiotem uprawnionym w zakresie publicznoprawnym, np. nie może uzyskać licencji na wykonywanie transportu drogowego ${ }^{19}$. Spółka nie jest także przedsiębiorcą rejestrowym. Spółka również nie może prowadzić działalności pod własną firmą, pod firmą działają jednak wspólnicy spółki będący przedsiębiorcami. Spółka cywilna może być natomiast płatnikiem podatku od towarów i usług.

Spółka cywilna nie ma podmiotowości prawnej, czego konsekwencje wyrażają się, między innymi, w tym, że stroną zawieranych

\footnotetext{
17 Wyrok NSA z dnia 3 lutego 2011 r., II FSK 838/2010, Lex nr 1012079.

18 Uchwała SN z dnia 6 listopada 2002 r., III CZP 67/02, OSNC 2003, nr 7-8, poz. 102.

19 Wyrok WSA w Warszawie z dnia 19 października 2006 r., VI SA/Wa 1161/06, Lex nr 298125.
} 
umów są wszyscy wspólnicy, a nie spółka, podmiotami praw i obowiązków są wszyscy wspólnicy, a nie spółka, majątek spółki jest majątkiem wspólnym wspólników, natomiast odpowiedzialność za zobowiązania ponoszą wspólnicy, a nie spółka oraz w tym, że występuje ona w obrocie, w tym także w procesie, wyłącznie poprzez wspólników.

$\mathrm{Na}$ tle prawa polskiego spółkę cywilną należy zaliczyć obecnie do jednostek organizacyjnych nieposiadających ani zdolności prawnej, ani osobowości prawnej, gdyż nie istnieje alternatywna kategoria prawna, umożliwiająca podkreślenie odrębności charakteru prawnego spółki cywilnej od stosunków obligacyjnych. Skoro spółka nie może być uznana w świetle legis latae za osobę, podmiotami praw i obowiązków spółki są wszyscy wspólnicy łącznie, prawa są przy tym niepodzielne z uwagi na ich przynależność do majątku odrębnego z nieokreśloną wielkością udziałów, a odrębność obowiązków wynika ze względów prawnych, a także faktycznych oraz sposobu ukształtowania odpowiedzialności za te obowiązki20.

$\mathrm{Na}$ gruncie prawa pracy podmiotowość posiada nie tylko jednostka nieposiadająca osobowości prawnej, ale również jednostka nieposiadająca zdolności prawnej. Pracodawcami są zatem: osoby fizyczne, osoby prawne, tzw. niepełne (ułomne) osoby prawne, czyli jednostki organizacyjne niebędące osobami prawnymi, którym ustawa przyznaje zdolność sądową (art. $33^{1} \S 1$ k.c.) oraz inne jednostki organizacyjne. $\mathrm{W}$ związku z tym wykształciło się swoiste rozumienie zdolności prawnej (zdolności do bycia pracodawcą) i pochodną takiego właśnie rozumienia pojęcia pracodawcy jest art. 3 k.p.

Pracodawcą jest każda jednostka organizacyjna mająca (nie tylko na podstawie przepisów powszechnie obowiązujących, ale również na mocy regulacji wewnętrznych) kompetencje do samodzielnego zatrudniania pracowników i podejmowania decyzji w sprawach ze stosunku pracy, choćby nie posiadała ona zdolności prawnej. W konsekwencji za pracodawcę uznaje się również wewnętrzną jednostkę organizacyjną określonego podmiotu prawa, jeżeli podmiot ten umocował swoją jednostkę wewnętrzną (a ściślej - osoby kierujące tą jednostką) do podejmowania decyzji $w$ indywidualnych sprawach pracowniczych $^{21}$.

\footnotetext{
20 M. Podleś, Charakter prawny spółki cywilnej na tle prawa polskiego i niemieckiego, Warszawa 2008, s. 73; postanowienie SN z dnia 17 czerwca 2014 r., II UZ 34/14, Lex nr 1487088.

21 M. Muliński, [w:] Kodeks postępowania cywilnego. Komentarz do art. 460 kpc, red. A. Góra-Błaszczykowska, Warszawa 2013, Nb 1-4, Legalis.
} 
Jednostka posiadająca przymiot pracodawcy powinna charakteryzować się następującymi cechami: samodzielnością działania w stosunku pracy, a więc samodzielnością w zatrudnianiu pracowników przyznaną ze względu na organizacyjne, finansowe i funkcjonalne wyodrębnienie, posiadaniem środków materialnych, posiadaniem własnej struktury organizacyjnej, umocowaniem kierownika jednostki do samodzielnego reprezentowania tej jednostki w stosunkach pracy i dysponowania środkami finansowymi ${ }^{22}$.

Jako jednostki organizacyjne spełniające te kryteria wskazać można zakłady wchodzące w skład wielozakładowego przedsiębiorstwa, oddziały spółki kapitałowej, samodzielne jednostki gospodarcze stowarzyszenia lub fundacji, niemające osobowości prawnej jednostki organizacyjne Skarbu Państwa (stationes fisci) i gminy (stationes municipii) jako osoby prawnej, np. takie urzędy jak ministerstwa, kancelarie naczelnych organów władzy państwowej, urzędy wojewódzkie, a także urzędy gmin oraz inne jednostki organizacyjne Skarbu Państwa i gminy.

Za pracodawcę może być uznana również jednostka organizacyjna należąca do osoby fizycznej, wykazująca powyższe cechy, a także jednostka organizacyjna niemająca osobowości prawnej i niewchodząca w skład żadnej osoby prawnej. Pogląd ten może budzić pewne wątpliwości, aczkolwiek znajduje on swoje umocowanie w treści art. $3^{1}$ k.p., w myśl którego za pracodawcę będącego jednostką organizacyjną czynności w sprawach z zakresu prawa pracy dokonuje osoba lub organ zarządzający tą jednostką albo inna wyznaczona do tego osoba, a przepis ten stosuje się odpowiednio do pracodawcy będącego osobą fizyczną, jeżeli nie dokonuje on osobiście czynności, o których mowa w tym przepisie ${ }^{23}$.

Wyjaśniając treść tego przepisu SN stwierdził, iż istotą regulacji $\mathrm{z}$ art. $3^{1}$ k.p. w zakresie dotyczącym wyznaczenia osoby do dokonywania za pracodawcę czynności w sprawach z zakresu prawa pracy jest jej wskazanie na innej zasadzie niż pełnomocnictwo, z czym wiąże się możliwość udzielania przez nią pełnomocnictwa do działania za pracodawcę ${ }^{24}$. Z kolei w innym judykacie SN przyjął, że w rozumieniu art. $3^{1}$

\footnotetext{
22 J. Brol, [w:] Kodeks postępowania cywilnego. Komentarz, t. II, red. K. Piasecki, Warszawa 2010, s. 391.

23 Ibidem, s. 389 i n.

24 Wyrok SN z dnia 8 czerwca 2006 r., II PK 315/05, OSN 2007, nr 11-12, poz. 159, s. 471.
} 
k.p. za osobę zarządzającą jednostką organizacyjną nie może być uznany członek organu zarządzającego 25 .

Przedmiotem wielu orzeczeń Sądu Najwyższego było rozstrzygnięcie, czy określona jednostka organizacyjna posiada cechy pozwalające na uznanie jej za pracodawcę. Sąd Najwyższy przyjąt, iż podmiot, który nie ma osobowości prawnej ani nie jest jednostką organizacyjną zatrudniającą pracowników nie ma zdolności sądowej i procesowej w sprawach z zakresu prawa pracy. Gospodarstwo pomocnicze samorządowej jednostki budżetowej może być uznane za pracodawcę tylko wówczas, gdy jego samodzielność obejmuje uprawnienie do zatrudniania pracowników ${ }^{26}$. W sporze o wynagrodzenie za pracę sędziego sądu rejonowego stroną pozwaną jest zatrudniający sędziego sąd rejonowyjako jego zakład pracy (obecnie pracodawca). Pracodawcą prezesa sądu rejonowego nie jest ani Skarb Państwa, ani też prezes Sądu Wojewódzkiego (obecnie Sądu Okręgowego), lecz sąd, w którym pełni on swoją funkcję ${ }^{27}$, z kolei zgodnie z innym orzeczeniem SN - w sprawie o zapłatę uposażenia sędziego w stanie spoczynku legitymowany jest sąd, w którym sędzia otrzymywał wynagrodzenie, a nie Skarb Państwa ${ }^{28}$. Zdolność sądowa i procesowa w sprawach $\mathrm{z}$ zakresu prawa pracy jest powiązana z podmiotowością w zakresie zatrudniania pracowników. Podmiot, który nie ma osobowości prawnej ani zdolności do bycia pracodawcą, nie ma zdolności sądowej ani procesowej w sprawie z zakresu prawa pracy - nie ma takiej zdolności wójt ${ }^{29}$.

Sąd orzekający może niejednokrotnie powziąć wątpliwość, czy dana jednostka wyposażona jest w przymiot pracodawcy, czy posiada zatem zdolność prawną na gruncie prawa pracy, a w konsekwencji również zdolność sądową i zdolność procesową w rozumieniu art. 460 k.p.c. W takiej sytuacji sąd może wezwać osobę działającą w imieniu pracodawcy, aby nie tylko wykazała odpowiednim dokumentem swoje umocowanie do działania $\mathrm{w}$ danej sprawie, ale również by przedstawiła dokument (dokumenty) potwierdzające posiadanie przez daną jednostkę wskazanych wyżej cech decydujących o posiadaniu zdolności prawnej, a w konsekwencji również zdolności sądowej i procesowej

\footnotetext{
25 Wyrok SN z dnia 3 kwietnia 2007 r., II PK 247/06, OSN 2008, nr 11-12, poz. 163, s. 481.

26 Wyrok SN z dnia 14 grudnia 2004 r., I PK 135/04, OSN 2005, nr 15, poz. 224.

27 Uchwała SN z dnia 23 lipca 1993 r., I PZP 30/93, OSN 1994, nr 6, poz. 123; wyrok SN z dnia 2 grudnia 2010 r., I CSK 111/10, Lex nr 1001270; wyrok SN z dnia 19 września 1996 r., I PRN 101/95, MoP 1997, nr 6, s. 246.

28 Wyrok SN z dnia 12 maja 2005 r., I PK 246/04, OSN 2006, nr 1-2, poz. 11.

29 Wyrok SN z dnia 25 września 2008 r., II PK 36/08, MoPr 2009, nr 10, s. 532.
} 
w sprawach z zakresu prawa pracy ${ }^{30}$. Szerokie rozumienie zdolności sądowej i procesowej pracodawcy obowiązuje nie tylko w postępowaniu odrębnym w sprawach z zakresu prawa pracy, ale również w sprawach z zakresu ubezpieczeń społecznych, w których pracodawca występuje w charakterze uczestnika postępowania (strony albo interwenienta ubocznego) ${ }^{31}$.

Za brakiem zdolności spółki cywilnej do bycia pracodawcą opowiedział się m.in. J. Brol ${ }^{32}$ argumentując ten stan faktem, iż spółka cywilna - po zmianach wprowadzonych przepisami ustawy z dnia 2 VII 2004 r. o swobodzie działalności gospodarczej - nie jest już jednostką organizacyjną. Przedsiębiorcami są bowiem jedynie wspólnicy tej spółki, a nie sama spółka. Autor słusznie podnosi, iż starsze orzecznictwo SN, przypisujące spółce cywilnej zdolność sądową i zdolność procesową w sprawach z zakresu prawa pracy, z uwagi na zmianę stanu prawnego, należy uznać za nieaktualne 33 .

Za trafny należy uznać pogląd, że przedsiębiorstwo (art. 551 k.c.) utworzone $\mathrm{w}$ ramach spółki nie może aktualnie zatrudniać pracowników we własnym imieniu i działa na rachunek wspólników ${ }^{34}$. Taka jednostka organizacyjna nie może być uznana za pracodawcę, gdyż spełnia tylko jedno określone przez art. 3 k.p. wymaganie, tj. posiada odpowiadającą zakładowi pracy formę organizacyjną, obejmującą substrat osobowy i techniczny potrzebny do wykonywania określonego rodzaju działalności i związanego z tym procesu pracy. Nie ma natomiast koniecznej dla uzyskania statusu pracodawcy zdolności zatrudniania we własnym imieniu pracowników. Podmiotami praw i obowiązków spółki są wszyscy wspólnicy łącznie i to oni są „zbiorowym" pracodawcą dla zatrudnianych pracowników ${ }^{35}$.

$\mathrm{Na}$ podstawie nieobowiązującego już art. $479^{7}$ k.p.c. ${ }^{36}$ sądy orzekające w postępowaniu w sprawach gospodarczych przyznawały

\footnotetext{
30 M. Muliński, [w:] Kodeks..., Nb 1-4, Legalis.

31 Ibidem, Nb 1-4, Legalis.

32 J. Brol, [w:] Kodeks..., s. 392.

33 Wyrok SN z dnia 7 listopada 1995 r., I PRN 84/95, OSN 1996, nr 12, poz. 170; wyrok SN z dnia 10 maja 1996 r., I PRN 63/95, OSN 1996, nr 23, poz. 355; wyrok SN z dnia 6 lutego 1997 r., I PKN 77/96, OSN 1997, nr 18, poz. 340; postanowienie SN z dnia 29 stycznia 1999 r., II UKN 507/98, OSN 2000, nr 11, poz. 447.

${ }^{34}$ L. Miroszewski, Czy spółka cywilna jest pracodawcą?, „Praca i Zabezpieczenie Społeczne" 2000, nr 9, s. 38.

35 Postanowienie SN z dnia 17 czerwca 2014 r., II UZ 34/14, OSNAPiUS 2015, nr 11, poz. 155; wyrok SN z dnia 13 marca 2012 r., II PK 170/11, Legalis nr 491864.

36 Uchylony ustawą z 16.11.2006 r. o zmianie ustawy - Kodeks postępowania cywilnego oraz niektórych innych ustaw, Dz.U. Nr 235, poz. 1699.
} 
niekiedy spółce cywilnej zdolność sądową ${ }^{37}$. W konsekwencji powstawały tytuły egzekucyjne, w których oznaczano spółkę cywilną jako podmiot zobowiązany. Jednakże do egzekucji ze wspólnego majątku wspólników spółki cywilnej nieodzowny jest tytuł egzekucyjny wydany przeciwko wszystkim wspólnikom, problemy wierzycieli zaczynały się już na etapie rozstrzygania wniosków w postępowaniu klauzulowym, z uwagi na to, iż spółka cywilna pozbawiona jest legitymacji procesowej biernej, sądy odmawiały nadania klauzuli wykonalności przeciwko wspólnikom spółki cywilnej na podstawie tytułu egzekucyjnego wydanego przeciwko spółce ${ }^{38}$. W ten sposób mieliśmy do czynienia z grupą tytułów egzekucyjnych bezskutecznych z powodu wskazania w nich jako zobowiązanego „podmiotu”, przeciwko któremu nie można było nadać klauzuli wykonalności, a orzeczenia sądowe zasądzające określone świadczenia od spółki cywilnej należały do kategorii sententiae inutiliter datae 39 .

Należy podkreślić, iż brak zdolności sądowej spółki cywilnej jest konsekwencją braku osobowości prawnej, a także zdolności prawnej tejże spółki. W przepisach art. 860 i n. k.c. nie sposób dostrzec jakąkolwiek podstawę do przypisania spółce cywilnej cech podmiotu prawa. W konsekwencji w orzecznictwie i doktrynie przyjmuje się, że spółka cywilna jest wyłącznie stosunkiem obligacyjnym powstałym na mocy umowy pomiędzy określonymi podmiotami ${ }^{40}$. Wspólny majątek wspólników spółki cywilnej objęty jest współwłasnością (wspólnością) łączną, co w świetle art. $863 \S 3$ k.c. oznacza m.in., iż w czasie trwania spółki wierzyciel wspólnika nie może żądać zaspokojenia z jego udziału we wspólnym majątku wspólników ani z udziału w poszczególnych składnikach tego majątku. Jeżeli zatem tytuł egzekucyjny został wystawiony wyłącznie przeciwko jednemu wspólnikowi albo niektórym wspólnikom, klauzula wykonalności może zostać nadana przeciwko tym wspólnikom. W tej sytuacji prowadzenie egzekucji z majątku

\footnotetext{
37 Uchwała SN z dnia 7 lipca 1993 r., III CZP 87/93, OSP 1994, nr 11, poz. 204; uchwała SN(7) z dnia 26 stycznia 1996 r., III CZP 111/95, OSNC 1996, nr 5, poz. 63.

38 Uchwała SN z dnia 7 lipca 1993 r., III CZP 87/93, OSP 1994, nr 11, poz. 204; postanowienie SA w Warszawie z dnia 29 września 1993 r., I ACz 312/93, Wokanda 1994, nr 1, s. 48.

39 J. Ciszewski, Wybrane problemy spółek cywilnych na tle niektórych orzeczeń sq̨dowych, „Problemy Egzekucji Sądowej” 1996, nr 17, s. 36.

40 Uchwała SN z dnia 31 marca 1993 r., III CZP 176/92, OSNC 1993, nr 10, poz. 171; uchwała SN(7) z dnia 26 stycznia 1996 r., III CZP 111/95, OSNC 1996, nr 5, poz. 63; H. Pietrzkowski, [w:] Kodeks postępowania cywilnego. Komentarz, t. 4, red. T. Ereciński, Warszawa 2009, s. 61 i n.; K. Pietrzykowski, [w:] Kodeks cywilny. Komentarz, t. II, red. K. Pietrzykowski, Warszawa 2011, s. 728.
} 
wspólnego wspólników jest niedopuszczalne, zaś egzekucję wszczętą uznać należy za bezzasadną. Egzekucja taka pozostaje w oczywistej sprzeczności z treścią tytułu wykonawczego, powinna zatem zostać umorzona na podstawie art. 825 pkt 3 in fine k.p.c.

Spółka cywilna nie może być traktowana w obrocie prawnym jako odrębny od wspólników podmiot prawa, który ma własną zdolność prawną i własną zdolność sądową ${ }^{41}$. W związku z tym, gdy wierzyciel występuje z roszczeniami przeciwko spółce cywilnej powinien pozwać wspólników tejże spółki. Jeżeli chce skierować roszczenie do majątku objętego współwłasnością łączną, to powinien pozwać wszystkich wspólników, gdyż tylko w ten sposób możliwe jest prowadzenie egzekucji z tego majątku, o czym jednoznacznie przesądza brzmienie art. 778 k.p.c., zgodnie z którym do egzekucji ze wspólnego majątku wspólników spółki prawa cywilnego konieczny jest tytuł egzekucyjny wydany przeciwko wszystkim wspólnikom ${ }^{42}$. Natomiast wierzyciel dysponujący tytułem wykonawczym wystawionym przeciwko określonemu wspólnikowi może prowadzić egzekucję z majątku osobistego tego wspólnika, a także do jego wierzytelności z tytułu udziału w zyskach, jeżeli wspólnicy dokonali podziału zysku, może także zająć prawo do dokonania podziału zysku oraz prawa przysługujące wspólnikowi na wypadek wystąpienia ze spółki lub jej rozwiązania ${ }^{43}$.

Za L. Miroszewskim ${ }^{44}$ należy wskazać, iż współdziałanie wspólników w celu osiągnięcia wspólnego celu gospodarczego oraz wyodrębnienie majątku (współwłasność łączna) nie determinuje istnienia jednostki organizacyjnej. Dopuszczenie jednostki organizacyjnej przez prawo (wyodrębnienie organizacyjne) może nastąpić: bezpośrednio przez przepis prawny - w przypadku spółki cywilnej brak jest takiego przepisu lub też przez odwołanie się do czynności prawnej, z którą można łączyć powstanie takiej jednostki - w tym wypadku będzie to umowa spółki, która musi mieć walor umowy założycielskiej, gdyż tylko wtedy spółka stanie się podmiotem prawa, jako wyodrębniona wobec wspólników jednostka organizacyjna. Umowa spółki cywilnej

\footnotetext{
41 Wyrok SN z dnia 7 listopada 2003 r., I CK 191/03, Lex nr 599507.

42 A. Rycak, [w:] Kodeks pracy. Komentarz do art. 262 k.p., red. Walczak, Warszawa 2015, Nb 104-105, Legalis; wyrok SN z dnia 6 lutego 1997 r., I PKN 77/96, OSNP 1997, nr 18, poz. 340; wyrok SN z dnia 21 czerwca 2007 r., I PK 1/07, OSNP 2008, nr 15-16, poz. 220; wyrok SN z dnia 4 listopada 2004 r.,I PK 25/04, OSNP 2005, nr 14, poz. 206; postanowienie SN z dnia 3 lutego 1995 r., II CRN 157/94, OSNC 1995, nr 7-8, poz. 116. ${ }^{43}$ H. Pietrzkowski, [w:] Kodeks...., s. 63.

${ }^{44}$ L. Miroszewski, Czy spółka..., s. 33-38.
} 
nie ma charakteru umowy założycielskiej, gdyż spółka pozostaje stosunkiem zobowiązaniowym, a „spółka” oznacza albo stosunek prawny spółki, albo ogół wspólników, albo majątek wspólny wspólników i jest jedynie skrótem językowym.

Kodeksowe ujęcie spółki cywilnej pozwala traktować ją jako co najwyżej wspólnotę interesów. 0 istnieniu jednostki organizacyjnej decyduje, między innymi, wyodrębnienie organizacyjne. 0 takowym możemy mówić, gdy dana jednostka odpowiada za zobowiązania wobec pracowników w zasadzie swoim wyodrębnionym majątkiem, natomiast nie odpowiadają za nie osobistym majątkiem osoby fizyczne lub prawne, które „za nią stoją”, chyba że co innego wynika z przepisów prawa lub czynności prawnej. Za zobowiązania spółki cywilnej odpowiadają solidarnie wspólnicy majątkiem wspólnym i majątkami indywidualnymi, tak więc nie ma tu mowy o odpowiedzialności spółki jako podmiotu, zatem to wspólnicy i tylko oni są zdolni to odpowiedzialności za zobowiązania, w tym takie, które mogą wynikać ze stosunku pracy. Podmiotami praw i obowiązków w stosunkach zewnętrznych spółki cywilnej są wspólnicy. Majątek spółki pozostaje przedmiotem praw majątkowych wspólników, jest więc ich wspólnym majątkiem. Wspólnicy spółki cywilnej mogą zatrudniać pracowników we własnym imieniu i są zdolni wobec nich ponosić odpowiedzialność za zobowiązania ze stosunku pracy ${ }^{45}$.

Istota spółki cywilnej nie zmienia się, gdy cel gospodarczy oznaczony w umowie spółki polega na prowadzeniu działalności gospodarczej, również takiej, która wymaga utworzenia przedsiębiorstwa. Przez prowadzenie działalności gospodarczej spółka cywilna nie staje się podmiotowo wyodrębnioną od wspólników jednostką organizacyjną nie jest więc pracodawcą. Przedsiębiorstwo służące wspólnej działalności gospodarczej stanowi tylko mienie wspólników, oni zaś pozostają podmiotami praw i obowiązków w stosunkach prawnych związanych $\mathrm{z}$ jego funkcjonowaniem. Koniecznym warunkiem uznania wyodrębnionej pod względem organizacyjnym i majątkowym jednostki organizacyjnej za pracodawcę jest zdolność zatrudniania pracowników a więc zdolność do nawiązywania, zmiany i rozwiązywania stosunków pracy. Jednostka taka może być pracodawcą, jedynie wówczas gdy występuje we własnym imieniu i ponosi bezpośrednią odpowiedzialność za zobowiązania wobec pracowników. Nie wystarczy, aby reprezentant jednostki organizacyjnej był upoważniony do czynności prawnych w zakresie stosunków pracy, ale jego upoważnienie ma świadczyć

45 L. Miroszewski, Czy spółka..., s. 35-37. 
o odrębności tej jednostki jako pracodawcy. Dlatego punktem wyjścia do rozważań o ewentualnej zdolności przedsiębiorstwa spółki cywilnej do zatrudniania pracowników jest kwestia reprezentacji tego przedsiębiorstwa jako odrębnego od reprezentacji spółki. Czy upoważniony zarządca przedsiębiorstwa może działać w imieniu przedsiębiorstwa, jako odrębnego podmiotu, czy też zawsze działa w imieniu wspólników. W ramach współdziałania w dążeniu do osiągnięcia wspólnego celu gospodarczego każdy ze wspólników jest uprawniony i zobowiązany do podejmowania działań zapewniających reprezentację spółki. Reprezentacja spółki cywilnej polega na działaniu we wspólnym imieniu i na wspólny rachunek wszystkich wspólników. Reprezentant przedsiębiorstwa utworzonego $\mathrm{w}$ ramach spółki cywilnej musi mieć wyraźne umocowanie od wspólników, gdyż dokonując czynności prawnych w ramach funkcjonowania przedsiębiorstwa, również tych które związane są z zatrudnieniem pracowników, działa wyłącznie w imieniu wspólników i z bezpośrednimi dla nich skutkami. Jego działanie jest więc wycinkiem uprawnień i obowiązków wspólników. Stąd, nie można mówić o odrębnej reprezentacji przedsiębiorstwa spółki cywilnej - a co za tym idzie, przedsiębiorstwo utworzone w ramach spółki cywilnej nie ma zdolności zatrudniania pracowników we własnym imieniu 46 .

Według niektórych przedstawicieli doktryny pracownicy zatrudnieni przez spółkę cywilną, w której choćby niektórzy wspólnicy byli osobami prawnymi, pozostają w stosunku pracy ze wszystkimi wspólnikami oraz z tymi spośród nich, którzy mają osobowość prawną, stąd też tego rodzaju spółka cywilna jest jednostką organizacyjną w rozumieniu art. 3 k.p. ${ }^{47}$. Takie stanowisko należy uznać za nieuprawnione, ponieważ przez uczestnictwo osoby prawnej jako wspólnika spółka cywilna nie staje się jednostką organizacyjną o odrębnej od wspólników podmiotowości w zakresie stosunków pracy. Błędne zdaje się być również zapatrywanie, jakoby zatrudnieni w takiej spółce pracownicy, których pracodawcą są występujący łącznie wszyscy wspólnicy, mają nadto tylu pracodawców, ile osób prawnych jest jej uczestnikami. Osoby prawne występowałyby jakoby pracodawcy w podwójnej roli - razem z pozostałymi wspólnikami, osobami fizycznymi oraz samodzielnie. To niejasne rozwiązanie staje się jeszcze bardziej złożone, jeśli zważyć, że osoba prawna realizowałaby w każdej z tych ról

\footnotetext{
46 L. Miroszewski, Czy spółka..., s. 36-38.

47 T. Liszcz, Pojęcie zakładu pracy $w$ według polskiego prawa pracy, „Annales Universitatis Mariae Curie-Skłodowska" 1980, vol. XXVII, s. 124-125.
} 
odmienne interesy. Brak jest podstaw prawnych do przyjęcia, że spółka cywilna jest jednostką organizacyjną, a przeto pracodawcą, gdy wśród wspólników znajduje się osoba prawna. Umowa spółki cywilnej nie służy tworzeniu jednostki organizacyjnej jako podmiotu prawa, niezależnie od tego, kto jest stroną tej umowy. Spółka cywilna, również z udziałem osób prawnych nie ma podmiotowości prawnej w zakresie stosunków pracy, a przymiot pracodawcy przysługuje wspólnikom ${ }^{48}$.

Wspólnicy (czy wspólnicy-przedsiębiorcy) tworzący spółkę cywilną nie są indywidualnymi pracodawcami pracownika, lecz każdy z nich działa jako pracodawca, tylko dlatego że jest w umowie spółki cywilnej i pozwala mu na to umowa spółki oraz ustawa. Pojęcie pracodawcy, przy określonej konwencji, nie może być całkowicie oderwane od podmiotowości (osobowości) prawnej, chodzi wszak o zakotwiczenie odpowiedzialności w określonym majątku, stąd wskazuje się tu na wspólników jako uprawnionych do działania za pracodawcę i odpowiedzialnych za pracodawcę, co nie znaczy, że pracodawcą jest tyle podmiotów ilu jest wspólników w spółce. W spółce cywilnej wspólnikiem może być nawet osoba prawna, co nie znaczy, że jest ona samodzielnym czy odrębnym podmiotowo pracodawcą dla pracownika ${ }^{49}$.

Podejmowanie czynności procesowych ma fundamentalne znaczenie dla wszystkich wspólników spółki cywilnej, bo wynik sporu może prowadzić do powstania po ich stronie solidarnej odpowiedzialności za zobowiązania. Zobowiązania spoczywające na wspólnikach spółki cywilnej nie są bowiem zobowiązaniami spółki, bo ta nie jest wyposażona w podmiotowość prawną i nie ma własnego „wyodrębnionego" majątku, lecz zobowiązaniami wspólników, regulowanymi z ich majątku wspólnego i osobistego ${ }^{50}$.

Co do zasady każdy ze wspólników jest umocowany do reprezentowania spółki tylko w granicach nieprzekraczających zakresu zwykłych czynności spółki. Ponieważ umocowanie do reprezentowania spółki wynika z przepisu ustawy, wspólnik reprezentuje spółkę jako przedstawiciel ustawowy wszystkich wspólników ${ }^{51}$. Taka podstawa przedstawicielstwa obowiązuje we wszystkich przypadkach, gdy prawo reprezentowania spółki jest związane z prawem prowadzenia

\footnotetext{
48 L. Miroszewski, Czy spółka..., s. 39.

49 Wyrok SN z dnia 13 marca 2012 r., II PK 170/11, Legalis nr 491864.

50 Wyrok SN z dnia 17 lipca 2007 r., II UK 278/06, OSNP 2008, nr 17-18, poz. 268.

51 S. Grzybowski, [w:] System prawa cywilnego, t. III, cz. 2, Wrocław 1976, s. 822;

A. Kidyba, Prawo handlowe, Warszawa 2009, s. 237.
} 
jej spraw, niezależnie od tego, czy realizowane jest na zasadach określonych w ustawie czy w umowie spółki ${ }^{52}$. Aczkolwiek Kodeks cywilny w żadnym miejscu nie zawiera definicji zwykłych czynności spółki, ocena, czy dana czynność przekracza zakres zwykłego zarządu, czy też nie, zależy od konkretnych okoliczności.

W orzecznictwie Sądu Najwyższego prezentowany jest pogląd, że podejmowanie w sprawie sądowej czynności procesowych ze skutkiem dla wszystkich wspólników spółki cywilnej przekracza zwykły zarząd, wobec czego nie jest możliwe wykonywanie ich przez jednego ze wspólników ${ }^{53}$. Prowadzi to do wniosku, że spółkę reprezentują wszyscy jej wspólnicy, chyba że umowa spółki lub uchwała wspólników wprowadzają odmienne uregulowania w tym zakresie. Przepis art. 866 k.c. nie precyzuje, w jakim zakresie umowa spółki oraz uchwała wspólników mogą odmiennie kształtować prawo reprezentowania spółki. Umowa z pewnością może je regulować w sposób generalny, mający zastosowanie do wszystkich czynności reprezentowania spółki. Określenie prawa reprezentowania w uchwale wspólników może mieć wymiar ogólny (wtedy w istocie stanowi zmianę umowy spółki, a więc powinna spełniać jej warunki) albo wymiar konkretny, czyli odnosić wskazane w uchwale zasady tylko do dokonania określonej czynności 54 .

Odmiennym zagadnieniem od sposobu podejmowania przez wspólników w sprawie sądowej czynności procesowych jest prawidłowe oznaczenie stron procesu (uczestników postępowania). W przypadku spółki cywilnej, potrzeba prawidłowego oznaczenia jego strony, którą nie jest ani jeden ze wspólników (chociażby uprawniony do reprezentacji), ani też spółka cywilna, lecz wszyscy jej wspólnicy ${ }^{55}$, wynika z faktu, iż po stronie wspólników spółki cywilnej zachodzi współuczestnictwo materialne konieczne, co stwarza legitymację procesową łączną, wymagającą występowania wszystkich wspólników w charakterze strony56.

\footnotetext{
52 K. Kopaczyńska-Pieczniak, [w:] Komentarz do art. 866 Kodeksu cywilnego, red. A. Kidyba, Warszawa 2010, Lex.

53 Uchwała SN (7) z dnia 26 stycznia 1996 r., III CZP 111/95, OSNC 1996, nr 5, poz. 63. 54 Postanowienie SN z dnia 17 czerwca 2014 r., II UZ 34/14, OSNAPiUS 2015, nr 11, poz. 155.

55 Postanowienie SN z dnia 17 czerwca 2014 r., II UZ 34/14, OSNAPiUS 2015, nr 11, poz. 155.

56 Uchwała SN z dnia 9 lutego 2011 r., III CZP 130/10, OSNC 2011, nr 9, poz. 100.
} 
Reasumując, podmiotem wszelkich praw i obowiązków wynikających ze stosunku pracy są wszyscy wspólnicy spółki cywilnej. Składając oświadczenia woli czy też wykonując zobowiązania, czynią to w imieniu własnym, nie zaś imieniu spółki cywilnej. Jakkolwiek należy dostrzegać autonomię prawa pracy względem innych gałęzi prawa (a wskutek tego - dopuszczam możliwość nadawania innego brzmienia pojęciom stosowanym na gruncie prawa pracy), to jednak należy przyjąć, iż wykładnia pojęć znajdujących się w ramach pewnego systemu prawnego nie powinna naruszać spójności tegoż systemu, czy co bardziej niebezpieczne być dokonywana contra legem. Wydaje się, że taka właśnie rozszerzająca wykładnia art. 3 k.p. (tj. uznająca spółkę cywilną za pracodawcę) pozostaje $\mathrm{w}$ dysharmonii przede wszystkim $\mathrm{z}$ procedurą cywilną, która przecież ma służyć ochronie uprawnień przyznanych przepisami Kodeksu pracy (można nawet przyznać, że ma charakter komplementarny względem norm materialnoprawnych). Dysonans pojęciowy może zatem uniemożliwić realizację praw, a z taką sytuacją mielibyśmy do czynienia w przypadku wyroku zasądzającego świadczenie na rzecz pracownika od spółki cywilnej. 